\title{
浅析草原生态环境保护及建设中存在的问题及对策
}

\author{
肖冰洁 \\ 沈阳市生态环境事物服务与行政执法中心
}

DOI:10.32629/eep.v3i2.649

[摘 要] 我国天然草原资源比较丰富,总面积近 4 亿公顷,占全国总土地面积的 $40 \%$,是耕地面积的 3 倍。草原是维持自然生态平衡和物种多样性的 主要系统, 同时还具有调节气候、涵养水源等作用。基于此, 本文结合理论实践,在简要阐述草原生态环境保护及建设意义的基础上,分析了目前 存在问题,并提出相应的解决对策,希望对我国草原生态环境保护有一定的参考和借鉴。

[关键词] 草原；生态环境；保护；建设

草原是组成生态环境系统的主要组成部分, 切实做好草原生态环境保 护及建设, 有助于丰富自然生态系统, 为物种进化提供良好的生存环境。随 着我国社会经济的飞速发展, 对草原生态环境造成了不同程度的破坏, 破 坏了原有的生态平衡, 急需采取一系列行之有效的方法和措施, 对其进行 保护, 以维持生态系统平衡, 实现人与自然和谐相处。基于此, 开展草原生 态环境保护及建设中存在的问题及对策的研究就显得尤为必要。

\section{1 草原生态环境保护及建设的意义}

草原是物种进化的主要场所, 独体的土层结构、气候条件、地理环境 等形成了草原独有的植被和生态系统。在草原上聚集了很多生物, 被称之 为物资资源库。合理利用草原资源和物种, 可实现人与自然和谐相处。草 原不但传承了悠久的历史文明, 而且通过上千年的发展, 在草原上形成了 独具特色的人类文化。草原生态环境保护及建设的主要目的是保护物种多 样化, 实现人与自然平衡发展, 契合持续发展理念。因此, 必须加强对草原 生态环境保护及建设的重视, 规范草原人民的生活生产, 努力构建一个良 性循环的自然生态系统。

\section{2 目前草原生态环境保护及建设中存在的问题}

2. 1 缺乏明确的保护及建设思路

随着生态保护和文明建设理念的深入人心, 人民逐步认识到保护草原 生态系统的重要性和必要性, 草原生态保护理念正在确立。但缺乏政策和 法律法规的支持, 缺乏统一规范的标准, 致使基层在保护草原生态环境上 存在较大分歧, 尤其是草原保护和建设思路还不够明确。

2.2 草原生态环境保护及建设缺乏持续性

草原生态环境保护和建设工作开展中存在很多限制因素, 致使各项工 作无法高效、有序的开展。具体表现为: 缺乏整体性, 各保护环节、建设 环节相互独立开来, 没有统一口径。甚至一些保护项目在开展时, 方式方法 及内容比较单一, 比如: 退牧还草是一项庞大的工程项目, 但个别草原对待 退牧还草的态度是仅仅限制在围栏和饲料补助上, 围栏虽然消耗了大量资 金, 但并没有起到良好的效果。此外, 畜牧生产方式、饲草料基地建设、草 场改良等工作整体性还比较差, 缺乏可持续性, 严重拖累了草原生态环境 保护及建设的步伐。

2. 3退牧还草面临的问题显著

现阶段, 我国草原牧区集约化还处于发展的初级阶段, 牧业发展的专 业化、社会化、网络化水平还比较低。主要原因体现是草原生态环境保护 及建设单位对牧区科技服务投入不足, 基础设施比较滞后, 无法满足牧区 草原生态环境保护及建设的需求。

\section{3 加强草原生态环境保护及建设的对策}

3. 1增强忧患意识, 明确保护及建设思路

第一, 必须充分认识到草原生态环境保护及建设的紧迫性和必要性,
通过电视、微信、微博、新媒体等先进的网络媒体做好宣传工作, 提升 人民草原生态环境的意识, 增强广大民众保护草原生态环境的责任感和 使命感。

第二, 准确认识草原生态系统的脆弱性和草原生态环境保护及建设持 续性。很多草原位于农牧交接地带, 人类活动比较频繁, 在开展活动时要做 到善待草原、保护草原。

第三, 草原生态环境保护要以草原自我修复为主, 开发和利用的进度, 必须滞后于草原的自我修复能力, 在保护中求发展, 保证生态效益和经济 效益相互平衡。

3. 2 做好生态移民工作, 缓减草原生态压力

草原生态环境保护及建设是一项比较复杂的工作, 涉及到的内容比较 多, 持续时间比较长。切实做好生态移民, 可有效缓减目前草原的生态压力, 既能改善牧民的生活质量, 又能为草原恢复生态系统提供良好的条件。因 此, 当地政府要结合目前草原上的生态容量, 综合分析中心城市吸纳能力, 考虑城乡建设规划发展实际情况, 有计划、有序的撤离牧区和半牧区等生 态环境比较脆弱地区的牧民。

3.3 出台优惠政策, 加快法制化建设步伐

为保证草原生态环境保护及建设工作能够顺利开展, 国家要尽快出台 更多的退牧还草、异地扶贫等项目, 以改进草原生产方式, 但这些项目涉及 到的资金比较大, 如果后续自己保障不足, 无法取得良好效果。考虑到现有 情况, 需要国家提升补助标准, 借鉴 “三农” 政策成功案例, 国家可对牧民 在畜种改良、饲草饲料良种、牧业机械购置都方面加大补助力度。

积极宣传最新出台的草原法、环境保护法等, 提升当地民众保护草原 的法律意识, 通过法律的手段来限制草原生态环境破坏行为, 严禁过度放 牧、超载放牧, 以保证草畜的平衡性。

\section{4 结束语}

综上所述, 本文结合理论实践, 分析了草原生态环境保护及建设中存 在的问题和对策。分析结果表明, 草原生态环境保护及建设是维持草原物 种多样性, 促使人与自然和谐相处的主要途径。针对目前存在的问题, 相关 单位和人员必须高度重视, 针对问题存在的根源, 制定行之有效的对策和 措施, 保证草原生态环境保护及建设有法可依、有迹可循。

\section{[参考文献]}

[1]沙依然古丽・巴孜肯.草原鼠害对草原的影响及防治对策[J].农家 致富顾问,2018(10):124.

[2]张振军.建平县林业生态建设存在的主要问题与对策[J].现代农村 科技,2019(6):12.

[3]李广忠. 草原鼠害对草原的影响及防治对策 [J]. 养殖技术顾 问,2007(04):21. 